\title{
Det springende punkt i engelsk gymnastikhistorie
}

\author{
af Grå Borup-Nielsen
}

Slår man op på nogle af de første sider i Vinterberg og Bodelsens dansk-engelske ordbog, finder man en fortegnelse over de mennesker, der var konsulenter for den første ordbogsredaktion. Konsulenterne er nævnt i alfabetisk rækkefølge - og når man har læst nogenlunde halvvejs gennem fortegnelsen, støder man på forstander H. G. Junker, der var konsulent for gymnastik.

Junker blev født i 1875, og da han efter sin uddannelse på Vinthers Seminarium i Silkeborg allerede i nogle år havde været gymnastiklærer, tog han den nyoprettede 1-årige uddannelse $\mathrm{i}$ svensk gymnastik på Statens Gymnastikinstitut. Det var fra 1899-1900.

I 1905 underviste Junker i England som assistent for K. A. Knudsen, der var gymnastikinspektør. Junker havde nemlig sendt K. A. Knudsen et brev, hvori han udtrykte sin utilfredshed med gymnastikkens daværende stade, men hvor han samtidig skitserede en række reformforslag for gymnastikinspektionen. Det var dette brev, der fik K. A. Knudsen til at opfordre Junker til at undervise som hans assistent på et kursus i svensk gymnastik i England i 1905. Dette kursus blev afholdt i Scarborough.

Kort efter kom en repræsentant for det britiske undervisningsministerium til Danmark for at finde en lærer, der kunne bistå med at indføre en egentlig gymnastikundervisning i engelske skoler. Uheldigt nok skiftede England regering, netop da Junker var blevet udset til denne opgave. I stedet skete der det, at the West Riding of Yorkshire LEA (: Local Education Authority) opfordrede Junker til at blive gymnastikinspektør. Her kendte man ham udmærket fra gymnastikkurserne i Scarborough. Junker blev, så vidt vides, den første mandlige gymnastikinspektør i England.

Fra 1905-1907 blev der af K. A. Knudsen hvert år holdt sommerkursus

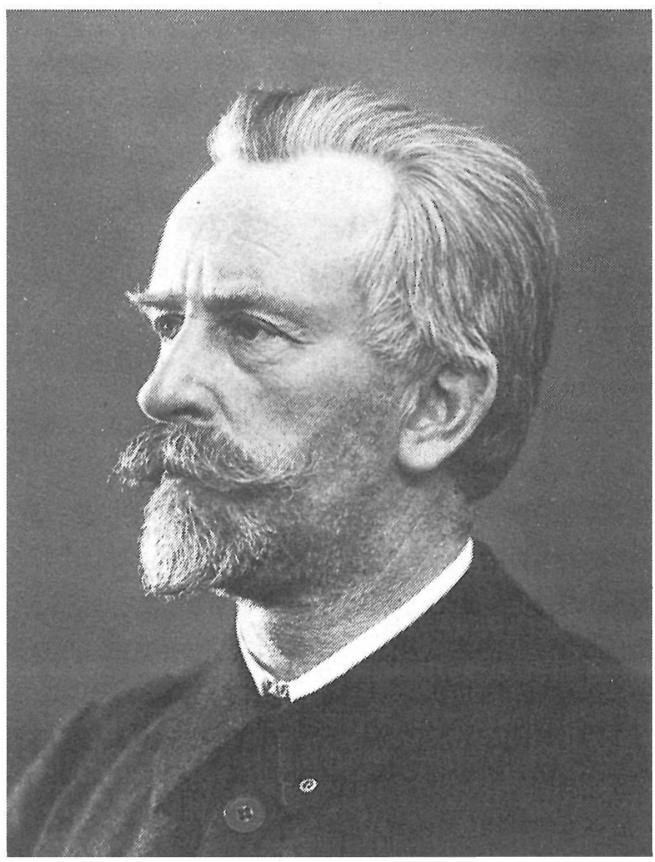

Forstander H. G. Junker. 
i svensk gymnastik efter Per Henrik Lings system. Ling var grundlæggeren af den svenske gymnastikundervisning, der hurtigt blev kendt udenfor landets grænser. Men så opfordrede K. A. Knudsen Junker til på egen hånd at afholde kurset. Det gjorde han i Silkeborg i 1908. Deltagerne var gymnastikinspektører, rektorer og lærere, heraf 24 fra the West Riding of Yorkshire, hvor Junker havde undervist og været gymnastikinspektør. I et par år underviste Junker i England om vinteren og i Danmark om sommeren, hvad der var spændende, men anstrengende. Så det førte til, at Junker frasagde sig sit hidtidige hverv i England og den 1. september 1910 tilbød en étårig gymnastiklederuddannelse $\mathrm{i}$ 'educational gymnastics' (: pædagogisk gymnastik) i Silkeborg.

Her kommer vi til det springende punkt: man havde på det tidspunkt $\mathrm{i}$ England ikke nogen egentlig gymnastiklæreruddannelse for mænd. »Det at være gymnastiklærer blev anset for at være et kvindeerhverv«, som en af gymnastikinstituttets tidligere lærere sagde til mig for nylig.

Dunfermline blev det første sted i Storbritannien, hvor man oprettede uddannelse i gymnastik for mænd. Det var derfor betydningsfuldt, at der fra Junkers Gymnastikinstitut udgik en lang række lærere, som i deres hjemland fik indflydelse $i$ deres egenskab af lærere og gymnastikinspektører. Udover de godt 2000 , der tog sommerkurser her indtil 1925, har omkring $370 \mathrm{i}$ årenes $1 \varnothing b$ fået certificat for den fuldstændige uddannelse ved Junkers Gymnastikinstitut. De mandlige gymnastiklærere afløste the Army PTI's (: Physical Training Inspectors), altså de Army Sergeant Majors, der havde fået deres gymnastikuddannelse på et militærakademi og som opretholdt deres militante stil, selv når de underviste skolebørn. Junkers gymnaster højnede standarden af undervisningen, hvor de kom hen, eftersom svensk gymnastik befandt sig på et højere niveau.

Da Junker besluttede sig for at starte sit eget gymnastikinstitut, ventede man, at han ville finde et egnet sted $i$ England. I stedet havde han planer om at drive et institut for engelsksprogede elever i sit hjemland. Dette blev starten til det gymnastikinstitut, han oprettede i Silkeborg i 1910. Her kunne både mænd og kvinder få en gymnastiklæreruddannelse.

Til trods for, at instituttets elever havde en lang rejse at betale - de kom jo fra det meste af den engelsksprogede verden - var denne uddannelse, hvor man betalte lavere skolepenge end i hjemlandet, billigere, end hvor de kom fra. Det betød, at der var forældre, som ellers havde været afskåret fra det af $\emptyset$ konomiske grunde, der nu kunne sende deres voksne børn på College.

Da første verdenskrig brød ud, blev det naturligvis en umulig opgave at have et gymnastikinstitut, hvor eleverne udelukkende var engelsksprogede. Så instituttet lå næsten stille i de år og blev i stedet henimod krigens slutning åbnet for rekonvalescenter. Disse betalende gæster sikrede familiens fortsatte eksistens.

Jeg har truffet to af de mennesker, der blev uddannet på Junkers Gymnastikinstitut før første verdenskrig, en kvinde og en mand. Dorothy Cuthbertson blev uddannet fra 1912-14. Jeg husker hende mange år senere stå med en rød-hvid-blå buket ved den mindeplade for Junker, der endnu ses i gym- 


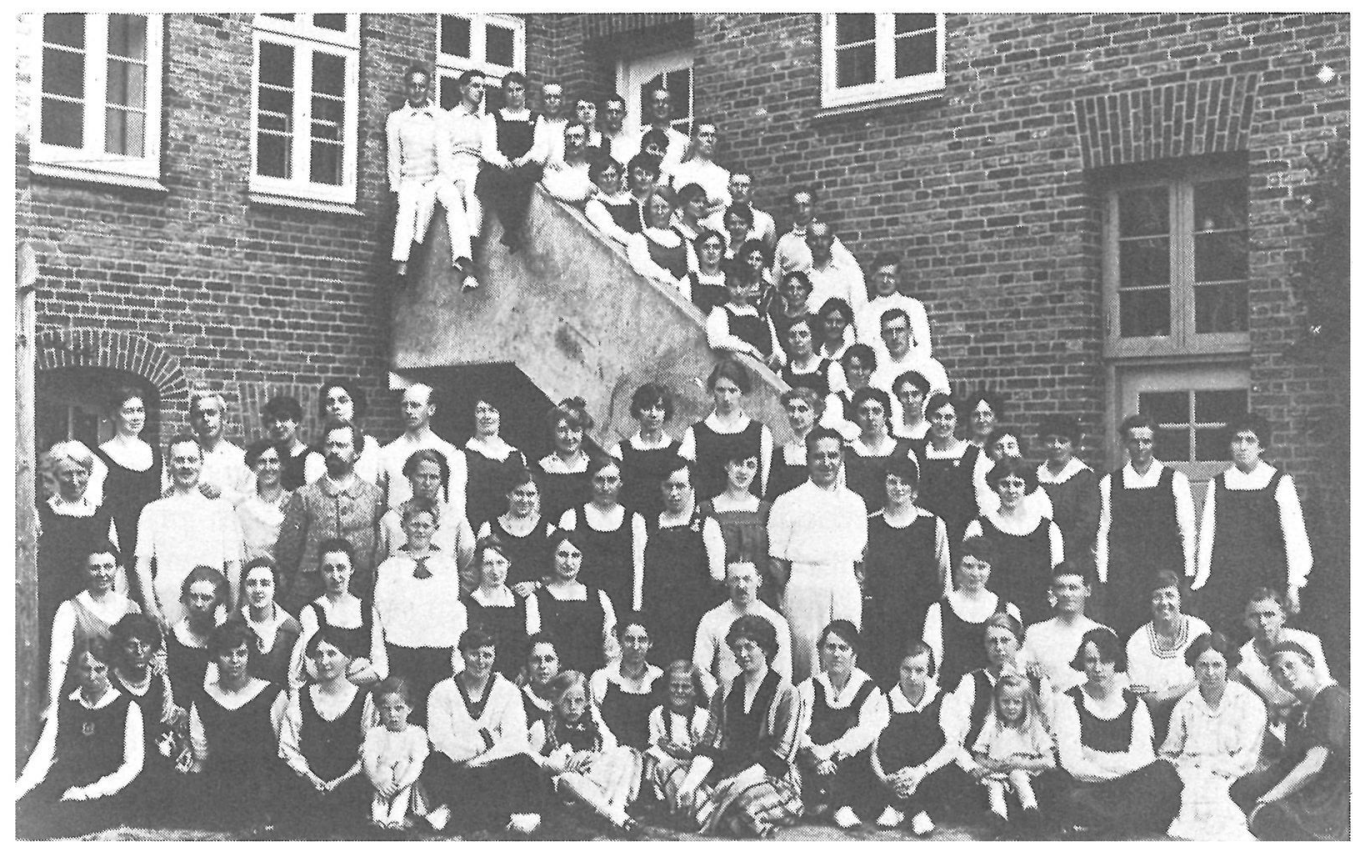

Elever og larere på Instituttets trappe.

nastikinstituttets mur. (Den bygning, der langt senere blev til »Gudenå Kurbad $\ll)$.

Ernest Major var så ung, da han kom som elev, at han lagde lidt til sin alder af angst for ikke at blive optaget. Han var faktisk 16 år, da han var færdig med den 1-årige uddannelse; men han indså, at han i så ung en alder ikke ville få ansættelse på nogen skole $\mathrm{i}$ England: Derfor valgte han at tage den étårige uddannelse om. Han bestod denne gang med udmærkelse i samtlige discipliner - og derefter var der ingen problemer med at få ansættelse. Han var på det tidspunkt den eneste mand $\mathrm{i}$ England med en to-årig gymnastikuddannelse bag sig. Siden blev han gymnastikinspektør i en alder af 21 - en af de aktive, der kun af og til sad ved sit skrivebord, men i stedet rejste rundt for at orientere sig om, hvad der foregik og for at hjælpe til rette. Han var meget afholdt og respekteret. Under 2. verdenskrig fik han majorsrang og blev således Major Major. Fra 1943-45 var han Chief Instructor ved the Army School of Physical Training i Aldershot. - Da 'The Silkeborg Old Students' Association' i forbindelse med en Reunion forhørte sig, om de kunne få adgang til at se portrættet af Churchill, der er ophængt i Dover Castle, sagde inspektøren for samlingen: »Der er desværre lukket om lørdagen.«Så sagde en af de tidligere lærere spontant: "Åh, det vil Major blive ked af." Hvorefter inspektøren spurgte: »Taler De om Major Major? Et prægtigt menneske. Han var min major under krigen. Jeg kommer selv og lukker op!«Ernest Major døde i foråret 1989 i en alder af 90 ; men så sent som i sommeren 1988 ledede han i sin egenskab af formand for de tidligere elevers forening en generalforsamling, hvor der 
skulle tages adskillige store og vanskelige beslutninger. En af disse skal jeg vende tilbage til.

Da første verdenskrig var forbi, genåbnede instituttet. Fra 1916 var uddannelsen to-årig, i 1929 blev den 3-årig. Dette sidste krav kom udefra. The Scottish Board of Education erklærede nemlig, at ingen fra da af ville kunne få ansættelse, med mindre de havde en tre-årig gymnastikuddannelse bag sig. Junkers Gymnastikinstitut havde imidlertid ikke faciliteter til at kunne fortsætte som blandet kollegium, efter at uddannelsen blev gjort tre-årig. Derfor blev det efter den tid udelukkende kvinder, der modtog uddannelse her eftersom de altid havde været $\mathrm{i}$ overtal.

Instituttet havde først til huse i en villa ved Gudenåen; man brugte da gymnastiksale og sportspladser, der tilhørte byens skoler. Grunden til den store, røde institutbygning blev støbt i 1914; men da 1. verdenskrig brød ud, måtte man i hast lægge tag over gymnastiksalen og i $\varnothing$ vrigt standse byggeriet. Den store, røde bygning, som i efterkrigstiden blev kendt som Gudenå Kurbad, stod færdig i 1924, og undervisninggen fortsatte, indtil den tyske invasionunder 2 . verdenskrig, hvor eleverne brat måtte rejse. Da tyskerne ville sætte dem fast, fik Junker den ordning i stand, at de blev indkvarteret hos danske familier og med jævne mellemrum skulle rapportere hos tyskerne. Modstandsbevægelsen hjalp en del af dem til Sverige, og nogle nåede hjem ad mange, krogede veje. Andre blev her i landet og er her endnu. Selve institutbygningen tog tyskerne under krigen til deres jyske hovedkvarter.

Men nu vil jeg gerne vende tilbage til den gode tid og sige et par ord om de fag, man underviste i på Junkers Gymnastikinstitut.

Det kan næppe komme bag på nogen, at undervisning i anatomi, fysiologi, hygiejne og gymnastikteori lå til grund for den praktiske undervisning $i$ gymnastik, dans og svømning. Al undervisning foregik på engelsk.

Den svenske gymnastik, der havde navn efter Per Henrik Ling, der havde grundlagt den, havde som princip, at man burde gå gradvis til værks, så at progressionen stemte overens med deltagernes formåen. Eleverne følte af og til, at de kunne komme slatne til en time, for så at opdage, at de efter undervisningen gik forfriskede bort.

Denne undervisning blev fulgt op af de timer i byens skoler, hvor eleverne selv lærte at undervise i gymnastik og sport og bagefter fik kritik af Junker eller en anden lærer plus de fire kammerater, der havde assisteret i timen. Ernest Major fortalte mig i sommeren 1988, at denne måde at give kritik på var en af de idéer, han tog med sig og anvendte i England.

Fagene på instituttet var foruden de før nævnte også: teoretisk og praktisk pædagogik, psykologi, øvelser i stemmebrug, sportens og dansens teori, patologi, førstehjælp og massage, som igen blev kombineret med sygegymnastik. Det var faktisk sådan, at patienter blev henvist til instituttet efter lægeordination.

Hertil kom en lang række muligheder for sportsaktiviteter: tennis, hockey, lacrosse, håndbold, langbold, badminton, sk $\varnothing j t e l \varnothing b$ og terrænl $\varnothing b$.

Når man betænker, at Junkers Gymnastikinstitut i snart 50 år har været uden lyden af bare fødder på gulvet $\mathrm{i}$ 


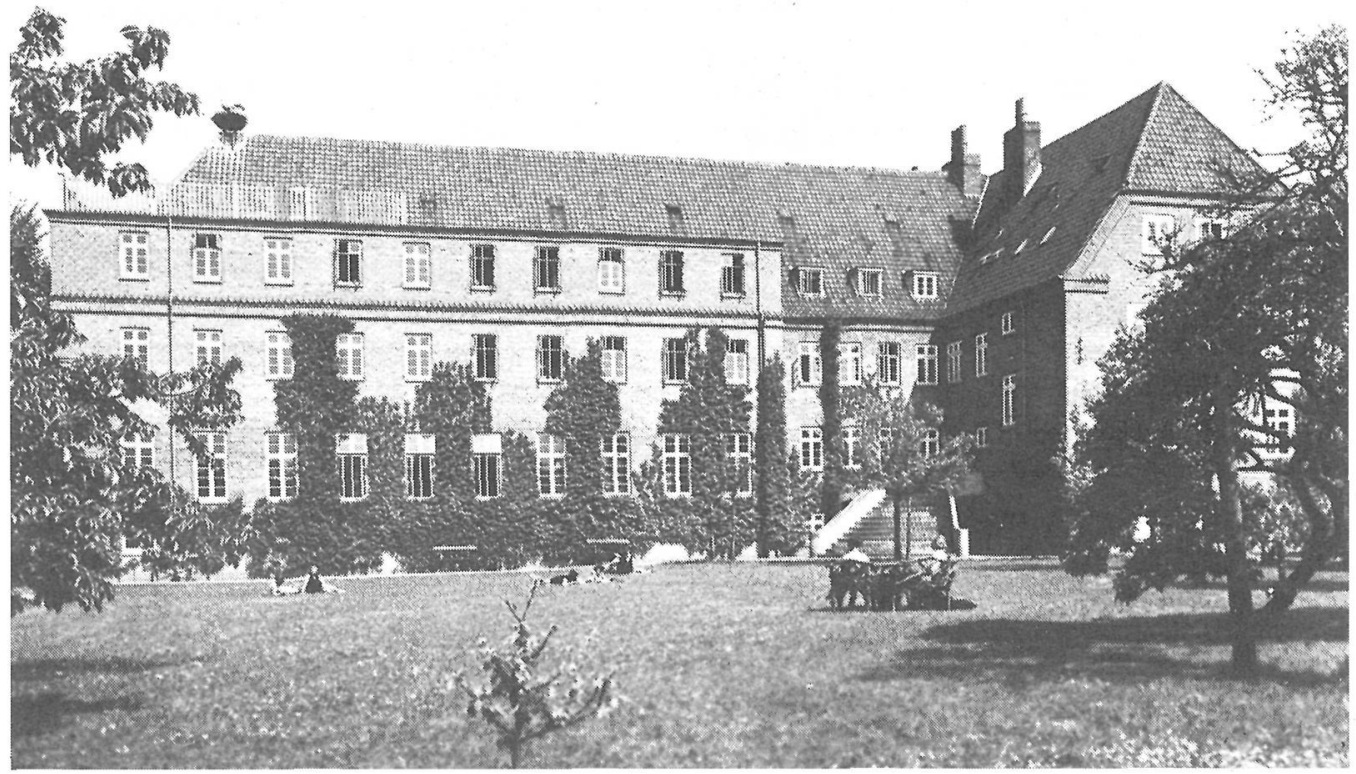

Junkers Gymnastikinstitut i Silkeborg.

gymnastiksalen, uden rungende kommandoer - og uden snakken, latter og institutjargon - er det imponerende, at de gamle elever og flere af lærerne endnu mødes til Reuion, nu i et antal af ca. 50 .

'The Silkeborg Old Students' Association' har i 55 år været en livskraftig forening, med egne love, bestyrelse og foreningsblad, der dels bringer generelle meddelelser eller artikler, dels $\mathrm{i}$ korthed beretter om de enkelte medlemmers tilværelse, som den former sig nu. Bladet er ældre end foreningen og blev første gang udgivet på gymnastikinstituttet i 1914. Det bærer navnet: 'Værsgo'.

Når der hvert år holdes Reunion, foregår det i regelen i England, men af og til i Danmark. I Silkeborg opsøger eleverne gammelkendte steder og gribes af nostalgi, bl.a. når der skal spi- ses. Jeg har været med til en festmiddag, hvor vi fik følgende tre retter: kærnemælkssuppe med rosiner, frikadeller og æbleskiver.

En af de store beslutninger, der måtte træffes på generalforsamlingen $i$ 1988 i 'The Silkeborg Old Students' Association', var den vemodige at bringe foreningens eksistens til ophør, medens det kan gøres med værdighed. Ingen er jo blevet yngre i de 50 år, der er gået, siden gymnastikinstituttet måtte lukke.

Derfor blev den Reunion, der fandt sted 18.-20. maj 1990 den sidste. Man udarbejdede ved den lejlighed et særligt fyldigt nummer af foreningsbladet, der belyste vigtige begivenheder og personer i instituttets historie - og man overdrog skriftligt materiale og fotografier i foreningens eje til Danmarks pædagogiske Bibliotek. 
Herefter vil mindepladen ved hushjørnet på den røde bygning i Silkeborg være det synligste bevis på, at H. G. Junker oprettede et internationalt gymnastikinstitut på dansk grund. Men den vældige indflydelse, det har haft, at en lang række engelsktalende lande har modtaget kandidater fra gymnastikinstituttet, skal naturligvis først og fremmest nævnes.

Ånden på instituttet, for en stor del skabt af hr og fru Junkers personlighed, og den uddannelse, man mødtes om, må have været noget særligt, når gamle elever og lærere har mødtes til nu. Det var et bæredygtigt eksperiment.

\section{Kilder}

Vinterberg og Bodelsen: Dansk-engelsk ordbog. Gyldendal 1954.

Barbare Chucher: "The Contribution of H. G. Junker and the Training of specialist Teachers at Silkeborg (Denmark) to the Development of Physical Education in Great Britain and Northern Ireland.«PTA Journal, 1986.

Bodil Meyer, født Junker: udklipsbog om Junkers Gymnastikinstitut. (Privateje).

A. Lundqvist Andersen og Jørgen Budtz-Jørgensen: Dansk Sportsleksikon, bind I, p 602. Standard Forlaget. 1944.

Specielt vil jeg gerne takke foreningens mangeårige sekretær, Mrs. Barbara Churcher, for omhyggelig og kritisk gennemgang af manuskriptet. 